\title{
Stridor: a rare complication of magnesium sulfate therapy in a pregnant patient
}

\author{
Adel Ganaw $^{1 *}$, Nissar Shaikh ${ }^{1}$, Tawfiq Abu-Aisha ${ }^{1}$, Raphael Samuel ${ }^{2}$, Firdous Ummunnisa ${ }^{3}$
}

${ }^{1}$ Department of anaesthesia/ICU perioperative Med: Hamad Medical Corporation. Doha-Qatar

${ }^{2}$ University of Kwa Zulu Natal, Durban: South Africa

${ }^{3}$ OBGY department AKH, Hamad Medical Corporation: Doha-Qatar

Received: 23 April 2015

Accepted: 10 May 2015

\section{*Correspondence:}

Dr. Adel Ganaw,

E-mail: adelganaw@yahoo.co.uk

Copyright: (c) the author(s), publisher and licensee Medip Academy. This is an open-access article distributed under the terms of the Creative Commons Attribution Non-Commercial License, which permits unrestricted non-commercial use, distribution, and reproduction in any medium, provided the original work is properly cited.

\begin{abstract}
Magnesium sulfate is frequently used in severe preeclampsia and eclampsia for the prevention and reoccurrence of seizure activity. Their adverse effects of magnesium sulfate are minor but it cause respiratory depression and tetany. We report a case of stridor due to laryngospasm as result of hypocalcemia in a pregnant patient on magnesium sulfate therapy. A 30 year old gravida5 para 4 had severe preeclampsia started on magnesium sulfate therapy and to control her hypertension she was on labetalol and nifidipine. One hour after the lower segment cesarean section, she developed severe laryngospasm and stridor, no upper airway secretion but found to have hypocalcemia. She responded to immediate intravenous calcium chloride with dramatic clinical improvement. Patients on magnesium sulfate can have life threatening hypocalcemia and stridor. The calcium channel blockers may augment the hypocalcaemic effect of magnesium sulfate.
\end{abstract}

Keywords: Calcium channel blockers, Eclampsia, Hypocalcemia, Laryngospasm, Magnesium sulfate, Preeclampsia and stridor

\section{INTRODUCTION}

Preeclampsia and eclampsia is a life threatening disorder affecting $2-8 \%$ of pregnancies. Magnesium sulfate is commonly used in Preeclampsia and eclampsia for prevention of seizure activity. ${ }^{1}$

But this therapy is not free from complications, usually minor adverse effects such as nausea, vomiting, muscle weakness, dizziness but can be major side effects such as respiratory depression and tetany. ${ }^{1}$

Rarely the hypocalcemia caused by magnesium sulfate therapy can lead to laryngospasm, which is not reported in the literature. We report a case of stridor due to hypocalcemia caused by the magnesium sulfate therapy in a pregnant patient.

\section{CASE REPORT}

A 30 year South African black lady, gravida 5, para 3+1, presented with sever preeclampsia (BP 215/145 $\mathrm{mmHg}$, proteinuria +2 ), and preterm premature rupture of membrane at 33 weeks of gestation. Her cardiovascular and respiratory examination was unremarkable. Past medical history she was known case of HIV, CD4 was unknown, she wasn't on ARVS therapy.

Up on presentation, she was given 10 grams magnesium sulfate (Mg. Sulfate) intramuscular, followed by 2 grams/hour intravenous $\mathrm{Mg}$ sulfate as a maintenance, as well as antibiotic and course of Betamethasone.

Blood pressure was dropped to $145 / 95 \mathrm{mmHg}$, the investigations (FBC, urea, creatinine, electrolytes, LFT, coagulation screen) were done, it showed raised serum creatinine $115 \mathrm{mmol} / \mathrm{l}$, and liver enzymes LDH 1433 
IU/l, ALP 162 IU/l hemoglobin 10 grams/dl other investigations were unremarkable.

After 3 hours of admission, blood pressure raised to $186 / 124 \mathrm{mmHg}$, controlled with Labetalol infusion and Nifidipine (10 mg orally). After 6 hours of admission patient had emergency cesarean section (LSCS) due to fetal distress. Patient underwent LSCS under spinal anesthesia.

After 1 hour of Cesarean section she was dyspnic, distressed, and had stridor, her blood pressure was 111/70 $\mathrm{mmHg}$, heart rate 76 beat/min, Glasgow Coma Score (GCS) 15/15, she had carpobedal spasm (Trousseau's sign), although there was no masseter muscle spasm (Chvostek's sign).

Table 1: Laboratory findings.

\begin{tabular}{|c|c|c|c|}
\hline & $\begin{array}{l}\text { At } \\
\text { presentation }\end{array}$ & $\begin{array}{l}\text { Pre- } \\
\text { operative } \\
\text { 13:00 } \\
\text { hours }\end{array}$ & $\begin{array}{l}\text { Post- } \\
\text { operative } \\
\text { 21:00 } \\
\text { hours }\end{array}$ \\
\hline $\begin{array}{l}\text { Hemoglobin } \\
\text { (gram/dl) }\end{array}$ & 13.7 & 13.3 & 11.7 \\
\hline $\begin{array}{l}\text { WBC } \\
\left(\times 10^{3} / \mathrm{mm}^{3}\right)\end{array}$ & 8.9 & 12.1 & 14.4 \\
\hline Platelet $\left(\times 10^{3}\right)$ & 197 & 197 & 161 \\
\hline $\begin{array}{l}\text { Sodium } \\
(\mathrm{mmol} / \mathrm{l})\end{array}$ & 135 & 134 & 136 \\
\hline $\begin{array}{l}\text { Potassium } \\
(\mathrm{mmol} / \mathrm{l})\end{array}$ & 3.5 & 3.5 & 4.1 \\
\hline $\begin{array}{l}\text { Chloride } \\
(\mathrm{mmol} / \mathrm{l})\end{array}$ & 109 & & 110 \\
\hline Urea (mmol/l) & 3.9 & 4.2 & 3.8 \\
\hline $\begin{array}{l}\text { Creatinine } \\
(\mathrm{mmol})\end{array}$ & 101 & 115 & 117 \\
\hline $\begin{array}{l}\text { Albumin } \\
\text { (gram/l) }\end{array}$ & 21 & 22 & 19 \\
\hline $\begin{array}{l}\text { Bilirubin } \\
(\mathrm{mmol} / \mathrm{l})\end{array}$ & 9 & 11 & 5 \\
\hline ALP (IU/L) & 150 & 162 & 131 \\
\hline LDH(IU/L) & 1287 & 1433 & \\
\hline ALT (IU/L) & & 35 & 28 \\
\hline GGT(IU/L) & 23 & 27 & 20 \\
\hline $\begin{array}{l}\text { INR } \\
\text { (International } \\
\text { Normal Ratio) }\end{array}$ & 0.82 & 0.82 & \\
\hline $\begin{array}{l}\text { Calcium } \\
(\mathrm{mmol} / \mathrm{l})\end{array}$ & & & 1.78 \\
\hline $\begin{array}{l}\text { Phosphate } \\
(\mathrm{mmol} / \mathrm{l})\end{array}$ & & & 1.55 \\
\hline $\begin{array}{l}\text { Magnesium } \\
(\mathrm{mmol} / \mathrm{l})\end{array}$ & & & 2.74 \\
\hline
\end{tabular}

Magnesium sulfate was stopped, $40 \% \mathrm{O}_{2}$ was given via face mask, $10 \mathrm{ml}$ of $10 \%$ calcium chloride was given was given over 10 minutes; she improved dramatically after $10 \%$ calcium chloride. Arterial blood gas, FBC, urea and electrolytes were sent, it showed low ionized calcium $0.89 \mathrm{mmol} / \mathrm{l}$, magnesium level was $2.74 \mathrm{mmol} / \mathrm{l}$ (Table1).

\section{DISCUSSION}

Worldwide the occurrence of Preeclampsia is about $2-8 \%$ of all pregnancies, most frequently it occurs after 32 weeks of gestation, some cases experience Preeclampsia at 20 weeks of gestation. Preeclampsia is one of leading cause of maternal death and perinatal morbidity and mortality. ${ }^{2}$ Eclampsia is one of major complication of Preeclampsia, affects 0.56 per 1000 pregnant women in developed countries.

Magnesium sulfate is the treatment of choice for prevention of convulsion in severe preeclampsia patient, also for prevention of repetitive seizures in eclmptic patient as it is confirmed by 2 clinical trials. The eclampsia trial collaborative group concluded that the Magnesium sulfate reduced the hazard of frequent convulsions in eclamtiptic patient by $52 \%$ when compared with diazepam. ${ }^{2}$ Magpic trial reported that the Preeclampsia patient had 58\% lower risk of getting eclampsia than the placebo group. ${ }^{2}$

The serum magnesium level should be between 4-7 meq/1 to prevent eclampsia. Magnesium acts via a number of mechanisms, such as decreasing calcium influx by blocking N-methyl D-aspartate receptors causing vasodilatation of cerebral blood vessels and reduces the cerebral vasospasm.,

Magnesium sulfate can cause several side effects such as flushing, nausea muscle weakness, respiratory depression, hypotension, hypocalcaemia, especially in patient with impaired kidneys function. Magnesium causes hypocalcaemia by inhibiting parathyroid hormone secretion and increases urinary excretion of calcium. ${ }^{2,3}$

Few case reports of symptomatic hypocalcaemia secondary to magnesium sulfate were published, one of the cases was critically ill eclamptic patient treated with large dose of magnesium sulphate and she had tetany when her serum magnesium was $10 \mathrm{mg} / \mathrm{dl}$ and her serum calcium was $6.7 \mathrm{mg} / \mathrm{dl}$.

Another case was preeclamptic patient, she received magnesium sulfate developed Chvostek's and Trousseau's signs 2 days after discontinuation of Magnesium sulfate, her serum calcium was $4.9 \mathrm{mg} / \mathrm{dl}^{4}{ }^{4}$

Calcium ion is one of most important ions in our body; it's involved in most of essential biological functions, such as muscle contraction, blood coagulation, release of hormones and neurotransmitters, and bone metabolism.

It's not surprising that abnormalities in calcium balance leads to significant physiological disturbance, the severity of these disturbances depend on severity of hypocalcaemia. Mild hypocalcaemia can lead to increase neuromuscular irritability, which may present with 
paresthesia of the feet and hand, circumoral numbness, muscular cramps. Severe hypocalcaemia leads to focal or generalized tonic muscle cramps, convulsions, arrhythmia, and laryngospasm and stridor which is common in pediatric population although has rarely been reported in adult age group. ${ }^{5}$

The most common causes of stridor in adults are swelling of the upper airway, pharyngeal and laryngeal edema, tumor and paralysis of the vocal cord.

In spite of strong evidences for effectiveness of magnesium sulfate concern has been expressed regarding the safety especially in situations where the capacity for patient monitoring is limited, patient with impaired kidneys function, concomitant use of magnesium sulfate and nifidipine as both of them affect calcium metabolism. ${ }^{2.4}$ Nifidipine alone does not appear to cause hypocalcaemia, but nifidipine may make hypocalcimic patient symptomatic. $^{4}$

Many studies have advocated that nifidipine and magnesium can be used safely together (Magpie trial $30 \%$ of patient received Nifidipine after they included in the study and no side effects were reported.

\section{CONCLUSION}

This case report should serve to remained clinicians of possibility of major complications of hypocalcaemia such as stridor especially if patients are receiving nifidipine with magnesium sulfate.
Funding: No funding sources

Conflict of interest: None declared

Ethical approval: Not required

\section{REFERENCES}

1. Steegers EA, Von Dadelszen P, Duvekot JJ, Pinjneborg R. Preeclampsia. Lancet. 2010;376:63144.

2. Smith JM, Lowe RF, Fullerton J, Currie SM, Harris L, Kantor EF. An integrative review of the side effects related to the use of magnesium sulfate for preeclampsia and eclampsia management. BMC Pregnancy Childbirth. 2013;13:34.

3. Eisenbud E, LoBue CC, Hypocalcemia after therapeutic use of magnesium sulfate. Arch Intern Med. 1976;136:688-91.

4. Stephine L. Koontz, Steven A. Friedman, Martin L. Schwartz, Symptomatic hypocalcemia after tocolytic therapy with magnesium sulfate and nifedipine. Am J Obstet Gynecol. 2004;190:1773-6.

5. G. Edward Morgan Jr, Maged S. Mikhail, Michael J. Murry. Abnormalities in calcium balance. In: G. Edward Morgan Jr, Maged S. Mikhail, Michael J. Murry, eds. Clinical Anesthesiology. 4th ed. New York: McGraw-Hill Medical; 2006: 685.

Cite this article as: Ganaw A, Shaikh N, Abu-Aisha T, Samuel R, Ummunnisa F. Stridor: a rare complication of magnesium sulphate therapy in a pregnant patient. Int $\mathbf{J}$ Reprod Contracept Obstet Gynecol 2015;4:1552-4. 